\title{
Study on the Conservation of Chinese Agricultural Land Resources Qi Meng ${ }^{1, a}$ \\ ${ }^{1}$ Sichuan Agricultural University, College of Literature and Law, Department of Law, 625014 \\ a email
}

\section{Keywords: Land Resources, Chinese Agriculture, Conservation Measures}

\begin{abstract}
In the concept of sustainable development has become a global consensus in the background, the face of continued population growth and modernization, to further improve the level of urbanization trends, based on Food Security to consider basic human survival and development needs, China must be strict and effective arable land protection policy, the central government to "cherish and rational use of land and effectively protecting farmland," as China's basic national policy, but continued to decline in arable land description of existing farmland protection policy did not achieve the desired results. Thesis, political economy analysis methods and modern economic theory and tools to explore our country continue to strengthen farmland protection system, the formation mechanism of economics continues to rise with GDP shrinking arable land behind this paradox, looking Economics existing farmland protection system causes inefficient operation, the adjustment of cultivated land resources protection system of the future to make recommendations with a view to future economic and social development of China's sustainable development of the state.
\end{abstract}

\section{Introduction}

Since the reform and opening up, China has achieved rapid economic development, but China's rapid economic development is worsening excessive consumption of resources and the environment for the price. One study showed that between 1989 to 2003, 66,160 percent of China to reduce the loss of cultivated land resources belong to inaction, Other experts believe that throughout the 1990s the average annual GDP growth of $9180 \%$ in about 4 to 6 percentage of resources and environmental costs (including natural resources, especially arable land resources depletion, ecological destruction and pollution). The focus of research is focused on the discovery of cultivated land resources, the establishment of a large number of development zones of China, township enterprises, the rise of factories, mostly based on cultivated land resources and the cost of the premise. According to statistics, from 1986 to 1996, so that only the occupation of cultivated land resources on reducing $9167-106 \mathrm{hm}^{2}, 10$ years, a net decrease of arable land resources $1193-106 \mathrm{hm}^{2}$, a net reduction from 1996 to 2006 between $8127-106 \mathrm{hm}^{2}$, in the use of this situation, the wheel planning to determine the 2010 target to maintain $1128-108 \mathrm{hm}^{2}$ farmland, forced, early 0-2005. Thereby to make a basic judgment: Behind China's economic take-off was the excessive consumption of resources and arable land occupation.

\section{Evolution Questions in Chinese Farmland Protection System}

Farmland protection system is to ensure that food safety regulatory system while maintaining the production capacity of arable substance formed. And the amount of cultivated land of long-term change trend corresponds to our farmland protection system and to be in reform and opening up as the boundary is divided into two stages, and the reform and opening up can be based on the national land management and specialized agencies set up "Land Management Law" Amendment and other typical events stage segment. And accompanied by green farmland protection system, the protection of arable land and arable land occupation tax system is to study the compensation system of farmland protection system indispensable element, a reflection of the state of distribution of the material interests of different stakeholders and adapt our cultivated land protection between. With other countries in the world, to our country, "cherish and rational use of land and effectively 
protecting cultivated land" as a basic national policy, strict land use control policies, but is different from the Western system of private land ownership, but China's industrialization, urbanization process brings concentration of population will inevitably lead to changes in the value of urban and rural land Marshall discussed, the distribution of material benefits in this condition changes the value of research is undoubtedly the focus of our current land tax system. In addition, the expropriation of arable land in our country that occurred between the State and organizations of rural collective land ownership transfer of land use from uses of arable land mainly for air to change cultivated land acquisition compensation system construction land refers to the authority in accordance with national law and procedures, organization of rural collective land should be given to the rural collective organizations and farmers' compensation system. Since 1949, China's arable land expropriation compensation system has gone through three stages of evolution, showing a different distribution pattern of interest. This part of the study of historical evolution, current situation of the three systems will be specifically analyzed, and to explore the possible reorientation.

Material interests between different stakeholders whether coordination is to improve the implementation of an important condition for farmland protection system effects. Farmland protection stakeholders can be distinguished on two levels. The first level is the central government on the use of arable farming, local government, village collective and farmers four stakeholders, both the central government or local governments expect from the food security point of view to play the best arable production capacity to ensure adequate farm supply, so the interests of both arable land protection goal is the same. After the cancellation of agricultural taxes, the rural collective economic ties between the organization and farmland is canceled, there is no economic motivation to ensure the implementation of central and local government farmland protection goals. At the same time due to the relatively lower earnings farming, farmers' enthusiasm for growing grain is not high, so the quality of farmland protection, especially protection of economic motivation is not strong; the second level is added to the land units on the land use change stakeholders. The central government's interest demands the pursuit of maximum economic growth while ensuring food security constraints in order to ensure social stability, and therefore have an incentive to protect farmland. However, economic growth indicators of performance evaluation system design to ensure that the needs of the construction land to become the optimal choice of local government, local government and therefore a decrease in arable land intrinsic motivation. Rural collective organizations to obtain arable land requisition compensation also have an incentive to reduce arable land. Land units who need land for construction is naturally motivated reduction of arable land. Farmers face a future right to development of the situation in deprived arable land use change, and thus have an incentive to protect arable land. As can be seen from the above analysis, the relationship between the interests of the current system for protecting farmland in relevant subjects are not coordinated, which is an important cause of farmland protection system implementation effect is not ideal, arable land continued to decline.

China's political system determines the government has strong protection of arable land, farmland protection from the relevant policies have been put in the analysis, the central government has a strong tendency to protect arable land, but the efficiency and effectiveness in the real world is not ideal, the most important the reason is the lack of legal level of protection of farmland various stakeholders mandatory binding, did not fully consider the basic role of market in resource allocation. Existing farmland protection is just "Land Management Law", "Property Law" and a few other official legal documents, low norms of behavior farmland protection system is still most binding level of regulations, departmental rules and regulations and other normative documents mainly. Establish land use control system in use on the annual plan, land requisition system and the government target responsibility system reflects the legislative process depends on the path of planned economic management system. According to the author to incomplete statistics, China's current land tax projects 34, only eight are tax projects, 26 projects are all other administrative expenses, tax knot this land. Our structure also reflects the farmland protection policy implementation is still dominated by administrative means, legal and economic means only in its infancy reality. 


\section{Farmland Protection Action of Central and Local Government}

First, we must strengthen the criminal law amendment farmland protection, will rise violate the resource protection of arable land act to endanger public safety height, to further improve the criminal law for resource protection of arable land provisions expressly protect arable land resources is to safeguard public interests and the need to ensure public safety to promote public participation in arable land resource conservation, the use of power of the state to strengthen the farmland resources protection, To further improve farmland protection responsibility goals assessment system, shared responsibility mechanisms improve the land preservation goals, develop assessment and evaluation methods, improve the assessment content, implementation of the accountability system, improve the system of accountability and correction mechanism, three to further deepen the reform of land expropriation system, strengthen the construction project site selection and evaluation of land, strictly control unreasonable requisition of farmland, total new construction land cannot be breakthrough food production and other crop production baseline demand for farmland, and resolutely eliminate all land and waste, and strictly control the scale and speed of the requisition of farmland, greatly improve the land acquisition process for new construction land use fees and land reclamation fees area collection standards, the practical implementation of additional land occupied by construction corporate responsibility, according to the balance of arable land occupied by construction requirements, strict implementation of the provinces (autonomous regions (municipalities additional land obligations, support qualified on the basis of the obligation to complete additional land to increase the supplementary Cultivated task of ensuring the protection of arable land to achieve the target of major national construction projects planned additional land mandate, approved by the State Council, through the implementation of land reclamation and development of major projects in the country overall arrangement, and actively promoting land consolidation and reclamation supplement arable land, efforts to broaden the financing channels, to explore market-oriented mode of operation, four to accelerate the establishment of compensation mechanism for protecting arable land to support migrant rural homestead reclamation of arable land, the establishment of balance of arable land indicators and indicators of remote rural construction land reclamation circulation mechanisms, building new arable economic incentives to implement the responsibility to protect arable land targets and interests of off-site transfers compensation to improve all levels of government to protect the enthusiasm of arable land, sum up and promote the establishment of Chengdu farmland protection fund of experience in the conditions of regions and cities, users of agricultural land, especially basic farmland protection, through the establishment of a compensation fund to protect agricultural land to farmers of protected areas appropriate subsidies, mobilize farmers to protect arable land of enthusiasm and initiative,

The process of urbanization protection of arable land resources, arable land protection and development is a process of combining cultivated land, to deepen rural land management as the most important resources, protection of arable land in the new period, really good job of rural land consolidation, and constantly open up farmland resources the protection of a new situation, a rural land remediation to object and the focus gradually shifted to the depopulation of rural areas on land for construction, the implementation of rural construction land elasticity exit mechanism, the establishment of farmers homestead exit farmland reclamation service system and new market indicators transaction mechanisms, the development of cultivated land resources, not only help to increase the income of migrant workers, but would also facilitate the development and utilization of existing farmers, second, to vigorously promote high and stable yield farmland improvement to focus on the construction of basic farmland, increase in low-yielding farmland efforts to actively carry out the construction of water conservancy, strengthening terracing and other soil and water conservation projects, promotion of water-saving technology, vigorously implement the project fertile soil, fertilizing and other major projects, raise the comprehensive production capacity of arable land, and actively organize implementation major projects of rural land remediation, promoting national food reserve core areas and strategic areas of construction, to ensure national food security, provide basic security, according to local conditions (conditions improve (improve 
quality requirements, vigorously carry out land leveling (in the field of road construction (farmland protection and construction of farmland water conservancy construction, strict regulation added cultivated land quality assessment and acceptance, steadily enhance the capacity of new arable land, arable land after remediation may be classified as basic farmland, the permanent protection of the three must be standardized to promote the construction of rural land remediation demonstration, remediation vacated rural construction land, the first reclamation of arable land, planning to continue as construction land, as farmers old renovation (new home construction (rural infrastructure and public service facilities land for construction, land development and rural non-agricultural industries, in the name of non-regulation, without breaking the overall land use planning and annual plans to expand the scale of urban land, rural land remediation is prohibited, the illegal adjustment (back and forced transfer of contracted farmers, four rehabilitation project to strengthen the final management and maintenance, to ensure that supplementary quality of cultivated land, according to the outcome of farmland, strengthen the occupation and supplement of arable land evaluation, from the number and capacity of both rigorous assessment balance of arable land, the quality does not meet the additional land occupied farmland quality, and increases in the mass conversion supplement of arable land, and actively implement the plow layer peeled project to encourage the peeling layer farming farmland used for construction, and soil and water conservation in compliance with the requirements under the premise of newly reclaimed land for construction, according to the quantity (quality and ecological comprehensive management and protection requirements, in accordance with Ratings on Different management and protection of arable land, special protection and other quality of paddy cultivated land, establishing human responsibility to protect arable land ledger management system, a clear case of the protection of basic farmland (area (arable land and other grades five through multiple channels to raise funds land remediation, large the magnitude of the increase of rural land remediation invested actively increase the levels of financial investment in rural land remediation, and explore innovative financial support to rural land remediation mode, the urban land requisition and occupation process of land occupation tax (new construction land compensation for the use farmland reclamation fees and expenses is mainly used for rural land remediation, promoting the effective integration of agriculture funds to strengthen the management of rural land remediation funds, actively guide and support farmers' participation in land remediation, land remediation to improve efficiency and reduce the cost of regulation and control of land, so that farmers land remediation process more directly benefit.

\section{References}

[1] Buchanan, J M, An Economic Theory of Clubs [J]. Economics, 1965, 32 (Fed).

[2] Burt, R Econometric Modeling of the Capitalization for Farmland Prices [J]. American Journal of Agricultural Economics 1986, 68.

[3] Catherine, B The Famer as conservationist [J]. American Journal of Alternative Agriculture2003, $18,4$.

[4] Costanza, R, Ralph d'Arge and Rudolf de Groot. The Value of the World s Ecosystem Services and Nature Capital [J]. Nature 1997, 387, 6630.

[5] Erik, Lichtenberg, C D Assessing Farm Land Protection Policy in China [J]. Land Use Policy, 2008 (25)

[6] Feige E L, Pearce D K. The Causal Relationship between Money and Income some Caveats for Time Series Analysis the Review of Economics \& Statistics 1979, 61, (4). 